\title{
粒度調整砕石内に敷設されたジオグリッドの 引抜き岡性に関する実験的検討
}

\author{
渡辺健治 1 栗山亮介 ${ }^{2}$
}

\begin{abstract}
本研究ではジオシンセティックス補強土一体橋梁の設計法の確立のために, 粒度調整砕石中に敷設したジオ グリッドの引抜き試験を行った . 引抜き試験では特に補強材の引抜き剛性に及ぼす拘束圧の影響, 補強材料の 影響に着目した . 拘束圧を変化させた試験では拘束圧が高いほど引抜き岡性は高い結果が得られた . これは拘 束圧の増加に伴い, 粒度調整䂶石 - 補強材間の摩擦抵抗か増加しただけでなく, 補強材の伸縮領域が減少した ことに起因していた . また，同一の拘束圧でも岡性の高い補強材を用いた場合，粒度調整砕石内での補強材の 伸びひずみ量が小さくなるため, 粒度調整砕石 - 補強材間での相対変位が小さく, 有効な摩擦抵抗力が広域で 発揮されやすくなることが分かった .
\end{abstract}

キーワード：ジオグリッド，引抜き試験，引抜き岡性，GR一体橋梁，性能設計

1.はじめに

著者らはインテグラル橋梁と側壁背面の補強土構造を 一体化させたジオシンセティックス補強土一体橋梁(以 下，GRS一体橋梁)の開発を行ってきた (図-1) ${ }^{1)}$. GRS 一体橋梁では, RC 壁体部と背面盛土間に生じる段差を 防止するために , 背面盛土に粒度調整砕石 (以下, 粒調 砕石) あるいは粒調砕石に若干のセメントを混合したセ メント改良磁土によって台形形状の盛土 (アプローチブ ロック) を構築する．GRS一体橋梁とアプローチブロ ックはジオグリッド (以下, 補強材) によって一体化さ れており，常時あるいは地震時に GRS一体橋梁に作用 する外力 (土圧, 慣性力等) に対しこのジオグリッドの 引張力か抵抗力として有効に作用している2).

GRS 一体橋梁のく体の設計においては, 補強材の引 抜き強度だけでなく引抜き岡性が必要である.特にく体 内に発生する曲げモーメントは, く体背面に敷設されて いる補強材の引抜き岡性の影響を大きく受ける。

既往の研究により，盛土中に敷設された補強材の引 抜き特性に関して実験的研究, 解析的研究力多く実施さ れているが，いずれの試験も引抜き強度や繰返し載荷に よる補強材の挙動に着目しており，盛土中に敷設された 補強材の引抜き岡性に関する研究は少ない，乥こで本研 究では, 粒調杂石中に埋設した補強材の引抜き岡性を評 価するために載荷試験を実施した . 載荷実験ては，模型 盛土内の拘束圧を変化させた実験や, 気中で岡性の異 なる補強材を用いた実験を行い, 引抜き岡性に及ぼす拘 束圧や補強材料の気中岡性の影響について考察したので 報告する

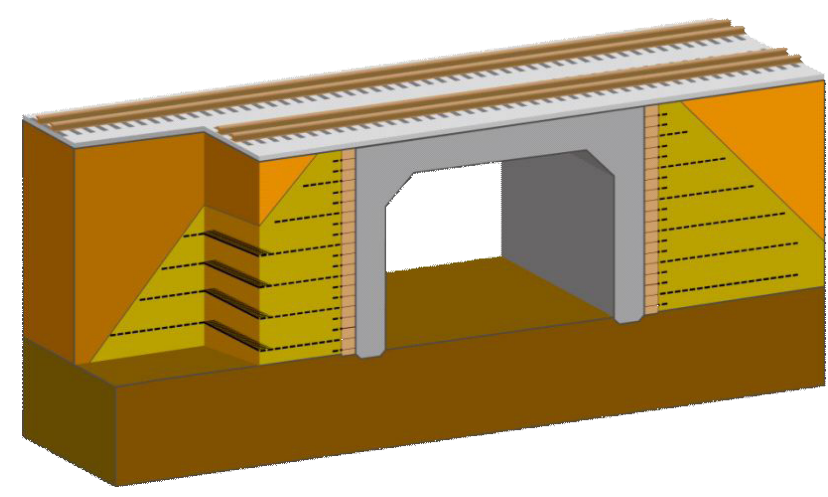

図-1 GR一体橋梁

2. 補強土構造物の設計に用いられるジオグリッ ドの岡性およひ損傷レベルについて

（1）盛土補強土擁壁 (RRR工法)

鉄道に広く普及している盛土補強土擁壁 (RRR工法) の壁体の設計においては，盛土内に敷設されている補強 材と壁体力定着されていることを考慮する . 具体的には， 壁体に作用する土圧や慣性力等を外力とし，補強材をば ね支点，壁体を連続梁としてモデル化する (図-2) ${ }^{3)}$. この場合, 設計の補強材の岡性 (ばね定数) としては気 中て実施した補強材の引張式験で算出した岡性（以下， 気中岡性) を用いる.補強材は盛土中に敷設されている ため, 実際には補強材の引抜き岡性は気中岡性よりも大 きいが，(1)補強材の引抜き岡性を精緻に求めることが困 難であること，(2)補強材の引抜き岡性を小さく与えるこ とにより壁体に発生する断面力を安全側に評価できるこ

1正会員 (公財)鉄道総合技術研究所 構造物技術研究部 主任研究員 (广1858540 東京都国分寺市光町2 838 )

2正会員 (公財) 鉄道総合技術研究所 構造物技術研究部 研究員 ( 1805840 東京都国分寺市光町2 838 ) 

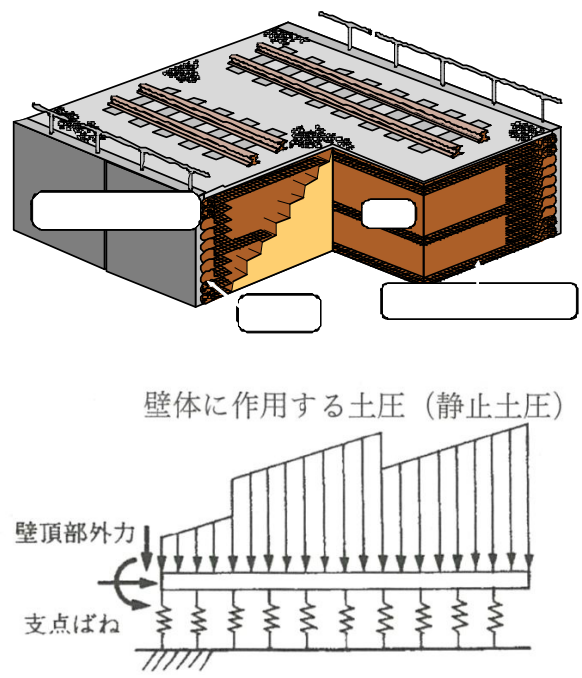

図-2 鉄道に用いられる盛土補強土擁壁と壁体設計の 際の補強材のモデル化

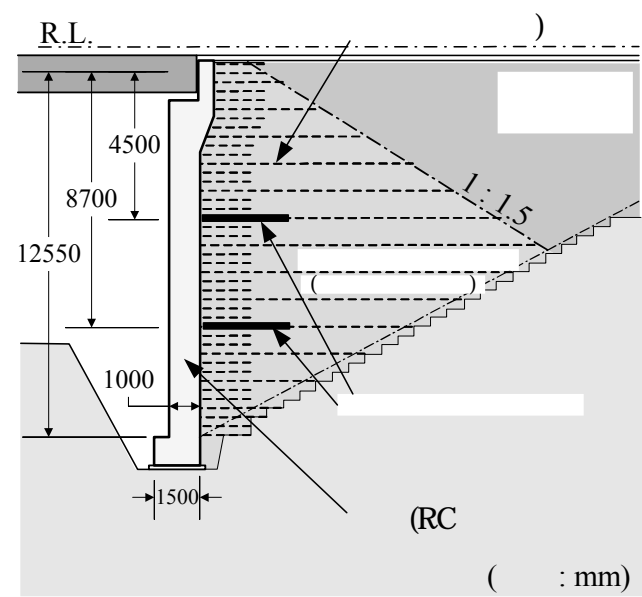

図-3 九州新幹線て建設された補強土橋台と補強材引 抜試験の概略図（文献6を修正）

と，などを考慮し気中岡性を設計に用いている．

なお，一般には補強材の気中岡性については文献4)

に示されているばね值 (Ks) を用いる.文献4)によると この試験は40cmの供試体 (チャック間距離) に対して 引張速度 $5 \% / \mathrm{min}$ で引張試験を行った際に得られた岡性 である。

（2）セメント改良補強土橋台 (以下, 補強土橋台) 逆T型橋台等 , 従来形式の抗土圧橋台では地震時に背 面盛土とRC構造物の接続箇所において段差が生じるこ とが多く，耐震上の弱点として指摘されていだ 5). 光 のため, 補強土工法を橋台に応用することにより耐震性 を飛躍的に向上させた補強土橋台力提案された .この補 強土橋台では, 背面盛土にセメント改良磢土によるアプ ローチブロックを構築し, 補強材によりアプローチブロ ックと橋台く体を一体化させている .

前述のRRR工法と異なり，補強土橋台は橋析を支持す

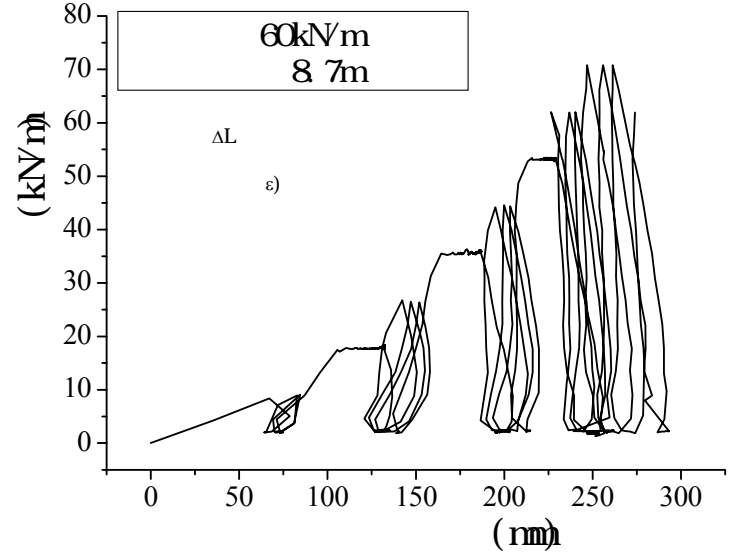

図-4 セメント改良磁土中に敷設されたジオグリッドの 引抜試験における引抜荷重-補強材自由長の関係 (文献5を修正)

表-1 鉄道標準における補強材の損傷レベルの定義およ び限界值の目安 ${ }^{3}$

\begin{tabular}{|c|c|c|}
\hline & 想定する限界状態 & 限界値の目安 \\
\hline $\begin{array}{c}\text { 損傷 } \\
\text { レベル } 1\end{array}$ & 無損傷 & 設計引張強度に達しない \\
\hline 損傷 & $\begin{array}{l}\text { 一部の補強材か塑 } \\
\text { 性化し，場合によ }\end{array}$ & $\begin{array}{l}\text { 設計引張強度に達し, 補強 } \\
\text { 土橋台の上部 } 1 / 3 \text { 補強材 }\end{array}$ \\
\hline レベル 2 & $\begin{array}{c}\text { っては補修が必要 } \\
\text { な状態 }\end{array}$ & $\begin{array}{c}\text { の伸ひひずみ } 3 \% \text { までを制 } \\
\text { 限値とする }\end{array}$ \\
\hline $\begin{array}{c}\text { 損傷 } \\
\text { レベル } 3\end{array}$ & " & 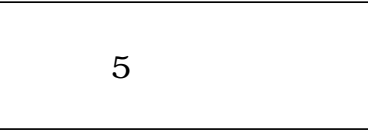 \\
\hline $\begin{array}{l}\text { 損傷 } \\
\text { レベル } 4\end{array}$ & $\begin{array}{c}\text { 補強材力破断に至 } \\
\text { る状態 }\end{array}$ & \\
\hline
\end{tabular}

るため，地震時に橋台く体に作用する慣性力はRRR工法 よりも大きくなる . そ穴たため, 橋台く体と定着している 補強材の岡性は橋台く体の耐震設計上, 大きな影響を及 ぼす. そのため, 九州新幹線において初めて構築された 補強土橋台了), 5 において, セメント改良碟土中に敷設さ れた補強材の引抜き試験か実施され (図-3) ${ }^{3}$ ), 補強材 ばね定数の設計用值か以下のように示されだ3)。

$\mathrm{K}_{\mathrm{gt}}=\mathrm{a}_{1} \times \mathrm{a}_{2} \times \mathrm{a}_{3} \times \mathrm{K}_{\mathrm{g}, 0}=37.5 \mathrm{~K}_{\mathrm{g}, 0}$

ここで， $\alpha_{1}$ : 補強材の伸縮領域に寄与する補正係数， $\mathrm{a}_{2}$ : セメント改良礫土内の拘束効果を考慮した補正係 数， $a_{3}$ : 補強材の巻き返しの効果を考慮した補正係数， $\mathrm{K}_{\mathrm{g}, 0}: 1.5 \mathrm{~m}$ 長さの補強材 (単位幅あたり) の気中でのば ね定数 $(\mathrm{kN} / \mathrm{m})$ である.

ここで上記a、については, 補強材の引抜き試験によ り得られた補強材自由長 (図-4) に基づき,セメント改 良磁土中に敷設された補強材の伸縮領域を400 mmと定め， $a_{1}$ を3.75(=1.5/0.4)としている．また，九州新幹線で実施 された実補強土橋台の水平載荷試験のや過去の模型振動

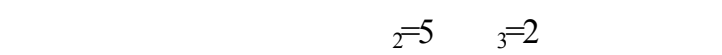


(3) 補強土構造物に用いられる補強材の損傷レベル

鉄道標準泒においては補強土構造物に対して性能照査 設計法力薄入されており，構造物の要求性能に応じた制 限值 (補強材の損傷レベル) が用いられる.表-1には補 強材の損傷レベルに対して想定する限界值，表-2には補 強土橋台の要求性能に対する設計限界值の設定例を示す． 損傷レベル1は補強材力弾性範囲内にあることを規定し ている，一方，損傷レベル2〜3ては引張力が補強材の設 計引張強度 $\left(\mathrm{T}_{\mathrm{d}}\right)$ に達することを許容するが，伸びすず み (3\%あるいは $5 \%)$ で補強材の損傷を定義している. これは，L2地震動か作用した場合，補強土構造物上層 の一部の補強材力設計引張強度に達した場合でも，発生 するひずみ量か限定的であれば補強材は破断せず，補強 土構造物は所用の耐震性能を満足できることを考慮した ものである . 前述のように , セメント改良礫土中に敷設 された補強材の伸縮領域は400mmと定められていること を考慮すると，L2地震動に対する復旧性の照査では補 強材の伸びの制限値 (=橋台く体上層部における水平変 位の制限值) は $12 \mathrm{~mm}(=400 \times 0.03)$ となり，L2地震動に 対する安全性の照査では制限値は $20 \mathrm{~mm}(=400 \times 0.05)$ と なる .

\section{3.補強材の引抜特性に関する実務設計上の課題}

(1)粒調砕石中に敷設された補強材の引抜き岡性

前章に述へだように, 鉄道の補強土構造物の設計には 補強材の気中岡性あるいはセメント改良碟土中の引抜き 岡性が用いられている．しかしながら，粒調砕石等の一 般の盛土材料中に敷設された補強材の引抜き岡性につい ては検討事例が少なく，十分な評価がされていない． 例えば在来線に適用される場合等，GPS一体橋梁の背面 盛土 (アプローチブロック) は粒調砕石で構築する場合 もあり，実務設計に際しては粒調砕石中に敷設された補 強材の引抜き岡性が必要となる.特に,

(1)引抜き岡性に及ぼす拘束圧の影響

(2)補強材の伸縮領域

の評価が重要になる . 表-1に示したように鉄道標準にお ける補強材の損傷レベルは伸びすずみで定義されている ため, 地震による構造物の水平変位の制限值を設定する ためには上記(2の評価が重要となる .

\section{(2)繰返し載荷を受けた場合の補強材の引抜特性の評価}

图-1に示したように，GPS一体橋梁には支承を設けず， 橋桁と側壁を一体化することにより耐震性を高めている . そのため常時においては橋桁の温度伸縮により補強材に は繰返しの水平力が作用する . 過去に鉄道総研において 構築したGPS一体橋梁の実物大模型の長期動態竐測》ににお いては, 補強材に2〜 4kN/n程度の繰返し引張応力が作用 していた . 盛土中に敷設された補強材に繰り返し載荷荷 重が作用した場合の引抜き特性についても検討事例が少 なく , 十分な評価がされていない .

表-2 鉄道標準における補強土橋台の要求性能に対する 補強材の設計限界值の設定 ${ }^{3}$

\begin{tabular}{|c|c|c|c|}
\hline $\begin{array}{c}\text { 補強土橋台の } \\
\text { 要求性能 }\end{array}$ & $\begin{array}{c}\text { 復|日性 } \\
\text { レベル1 }\end{array}$ & $\begin{array}{c}\text { 復|旧性 } \\
\text { レベル2 }\end{array}$ & $\begin{array}{c}\text { 安全性 } \\
\text { (地震時) }\end{array}$ \\
\hline $\begin{array}{c}\text { 補強材の損傷レ } \\
\text { ベルの限界値 }\end{array}$ & 1 & 2 & 3 \\
\hline $\begin{array}{c}\text { 一般に考慮する } \\
\text { 地震動 }\end{array}$ & L1地震動 & L2地震動 & L2地震動 \\
\hline
\end{tabular}

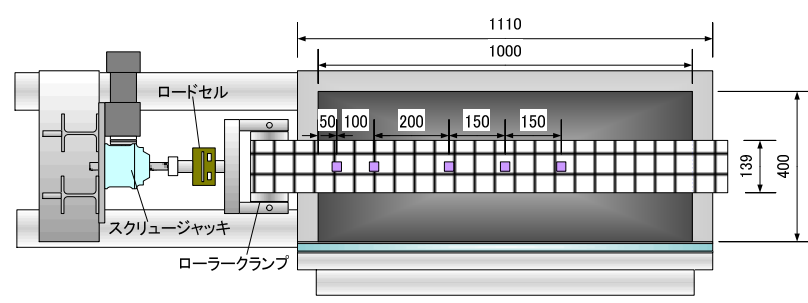

(a)上面図

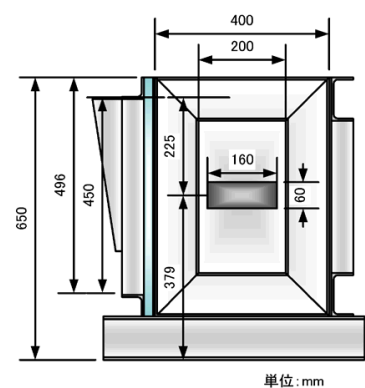

(b) 正面図

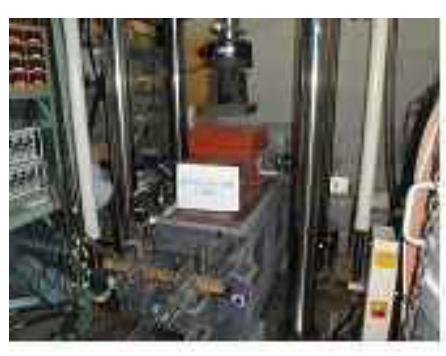

(c)試験模型写真

図-5 試験模型の概要図

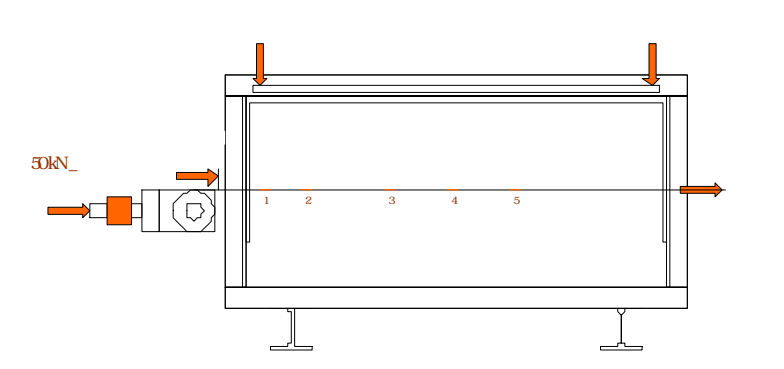

図-6 計測器の配置図

本研究では上記(1)に着目し,地盤の拘束圧や補強材 の気中岡性の影響について検討を行ったのて報告する .

\section{4. 引抜き試験の概要}

（1）模型地盤，試験に用いた補強材について

図-5に二試験模型の概要図，表-3に各試験に用いた補強 材の種類, 上載圧を示す . 実験は合計4ヶース実施した が，Case1およびCase2では同一の補強材，地盤模型を用 い, 拘束圧のみ変化させて実験を行った .一方, Case3, 4では補強材の引抜き特性に及ぼす気中岡性の影響を評 価するために，地盤模型，拘束圧を同一とし，気中岡性 
表-3 試験ケース

\begin{tabular}{|c|c|c|c|c|c|c|c|c|c|c|}
\hline \multirow[b]{2}{*}{$\begin{array}{c}\text { ケース } \\
\text { 名 }\end{array}$} & \multicolumn{5}{|c|}{ 載荷試験条件 } & \multicolumn{5}{|c|}{ 補強材の種類 } \\
\hline & 拘束圧 & $\begin{array}{c}\text { 深さ } \\
\mathrm{GL}(\mathrm{m})\end{array}$ & $\begin{array}{l}\text { 上載圧 } \\
(\mathrm{kPa})\end{array}$ & 計画最大荷重 & $\begin{array}{c}\text { クランプの } \\
\text { 種類 }\end{array}$ & 名称 & 主材 & $\begin{array}{c}\text { 引張強度の } \\
\text { 規格値 } \\
\mathrm{Tk}(\mathrm{kN} / \mathrm{m})\end{array}$ & $\begin{array}{l}\text { 目合い } \\
(\mathrm{mm})\end{array}$ & $\begin{array}{c}\text { 気中剛性 } \\
\text { 文献4) }\end{array}$ \\
\hline case1 & 高い & GL- $5.0 \mathrm{~m}$ & 100 & $\begin{array}{l}\text { 破断強度 } \\
(38 \mathrm{kN} / \mathrm{m})\end{array}$ & \multirow{2}{*}{ 平チャック } & \multirow{2}{*}{ KJ V- 3000} & \multirow{2}{*}{$\begin{array}{l}\text { ビニロン } \\
\text { 繊維 }\end{array}$} & \multirow{2}{*}{38} & \multirow{2}{*}{$20 \times 20$} & \multirow{2}{*}{$\mathrm{Ks}=200 \mathrm{kN} / \mathrm{m}$} \\
\hline case2 & 低い & GL- $0.5 \mathrm{~m}$ & 10 & $\begin{array}{c}\text { 引抜き抵抗力 } \\
(20 \mathrm{kN} / \mathrm{m})\end{array}$ & & & & & & \\
\hline case3 & \multirow{2}{*}{ 低い } & \multirow{2}{*}{ GL- $0.5 \mathrm{~m}$} & \multirow{2}{*}{10} & $\begin{array}{c}\text { 引抜き抵抗力 } \\
(28 \mathrm{kN} / \mathrm{m})\end{array}$ & \multirow{2}{*}{$\begin{array}{l}\text { ローラー } \\
\text { クランプ }\end{array}$} & DH- 100 & $\begin{array}{l}\text { ナイロン } \\
\text { 66繊維 }\end{array}$ & 101 & $15 \times 23$ & $\mathrm{Ks}=290 \mathrm{kN} / \mathrm{m}$ \\
\hline case4 & & & & $\begin{array}{c}\text { 引抜き抵抗力 } \\
(28 \mathrm{kN} / \mathrm{m})\end{array}$ & & KJV- $60 \mathrm{~W}$ & $\begin{array}{l}\text { ビニロン } \\
\text { 繊維 }\end{array}$ & 106 & $20 \times 20$ & $\mathrm{Ks}=980 \mathrm{kN} / \mathrm{m}$ \\
\hline
\end{tabular}

が異なる補強材を用いて試験を行った。

地盤模型は $10 \mathrm{~mm}$ 以上の粗粒分を除去したM40粒度調 整砕石を用い, 最適含水比 $(5.0 \%)$ において, 締め固 め密度比 $87 \%$ 程度て作成した . 模型地盤 (高さ450mm) の中央高さ付近に幅 $138 \mathrm{~mm}$, 長さ700mm (Casel, 2) ある いは1000mm (Case3, 4) の補強材を敷設した . 奥行き方 向への補強材張力の到達深さを確忍するため, 載荷点か

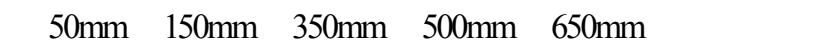
ずみゲージを中央のストランドに貼り付けた .ひずみゲ 一ジの貼り付け方法は文献6) と同樣であり，発生張力 とひずみゲージの出力值には完全な線形関係は得られな いが, 補強材張力の到達深さについて評価できることが 確認されている.補強材についてはCase1, 2ではビニロ ン繊維の補強材（引張強度の規格值 $\mathrm{T}_{\mathrm{k}}=38 \mathrm{kN} / \mathrm{m}$ ) , Case4 では引張強度の規格值の異なるビニロン繊維の補強材

$\left(\mathrm{T}_{\mathrm{k}}=106 \mathrm{kN} / \mathrm{m}\right)$ を用いた .一方, Case3では引張強度の 規格值や目合いはCase4と同等であるが気中剛性が大き く異なるナイロン66䋊維の補強材を用いた .

図一の二計測器の配置図を示す. 計測は補強材の引抜き 力, 作用方向の引抜き量, 補強材のひずみ, 土槽背面か らの補強材の引抜け量について行った .

\section{(2)載荷方法}

引抜き力はスクリュージャッキにより一定の載荷速度 $(1 \mathrm{~mm} / \mathrm{min})$ で与えた . 計画最大荷重は補強材の引張強

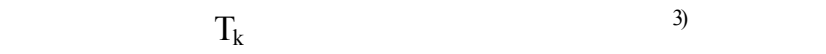
さい方とした．炎の結果，拘束圧の低いCase2のみ補強 材の引抜け抵抗力て計画最大荷重が決定し, 拘束圧の高 いCase1, 3,4について補強材の破断強度て言十画最大荷重が 決定した . 図一7に示したように. 本試験は補強材の計画 最大荷重を8分割した各段階て繰返し載荷を行った。. 各 段階の繰返し回数は3回とし各段階における最大荷重で 60 分, 除荷時で5分の荷重保持を行った。除荷時は $300 \mathrm{~N}$ の荷重を保ち補強材のゆるみを防いだ . 試験は補強材の 破断あるいは地盤からの引抜けか完全に生じるまで行っ た。

なお，Case1,2ではクランプとして平チャックを用いて 試験を行ったが, Case3,4では各ストランドにより均等に 引張力を作用させるためにローラークランプを用いた .

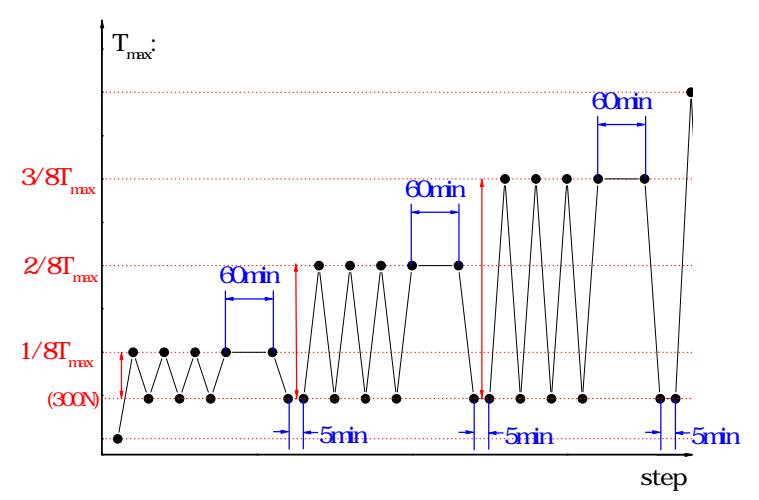

図 7 引抜試験における載荷パターン

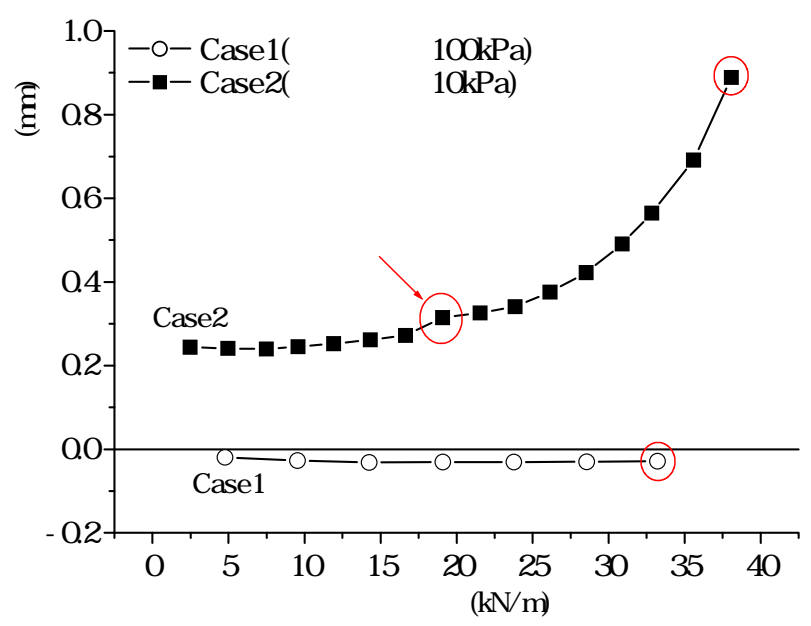

図-8 引抜き力と土槽背面からの引抜け量の関係

\section{5 . 実験結果および考察}

（1）補強材の引抜特性に及ぼす拘束圧の影響について 本節では，拘束圧の影響に着目して実施したCasel， Case2についての実験結果を示す . 図-8に引抜き力と土 層背面からの補強材の引抜き量の関係を示す . Case2で は引抜け抵抗力の計算值である $20 \mathrm{kN} / \mathrm{m}$ 付近で土層背面 

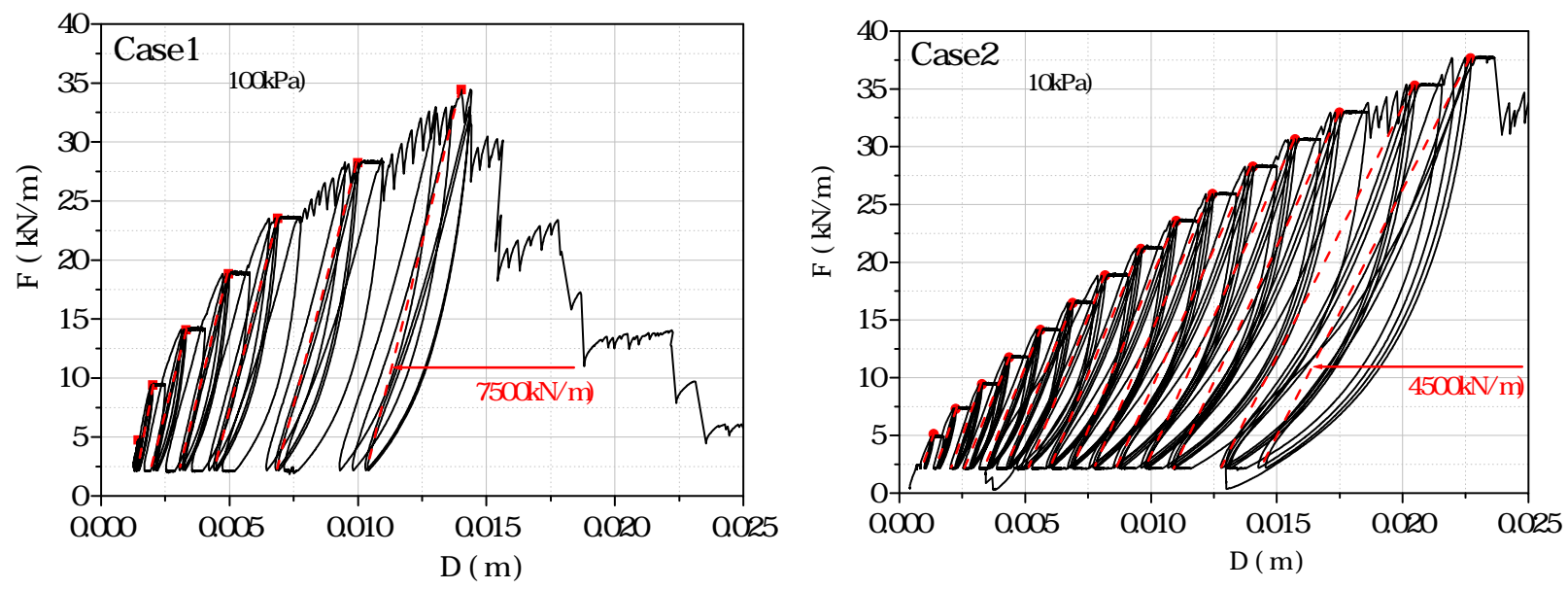

图-9 引抜き力と載荷点における引抜変位量の関係 (Cose1, Case2)
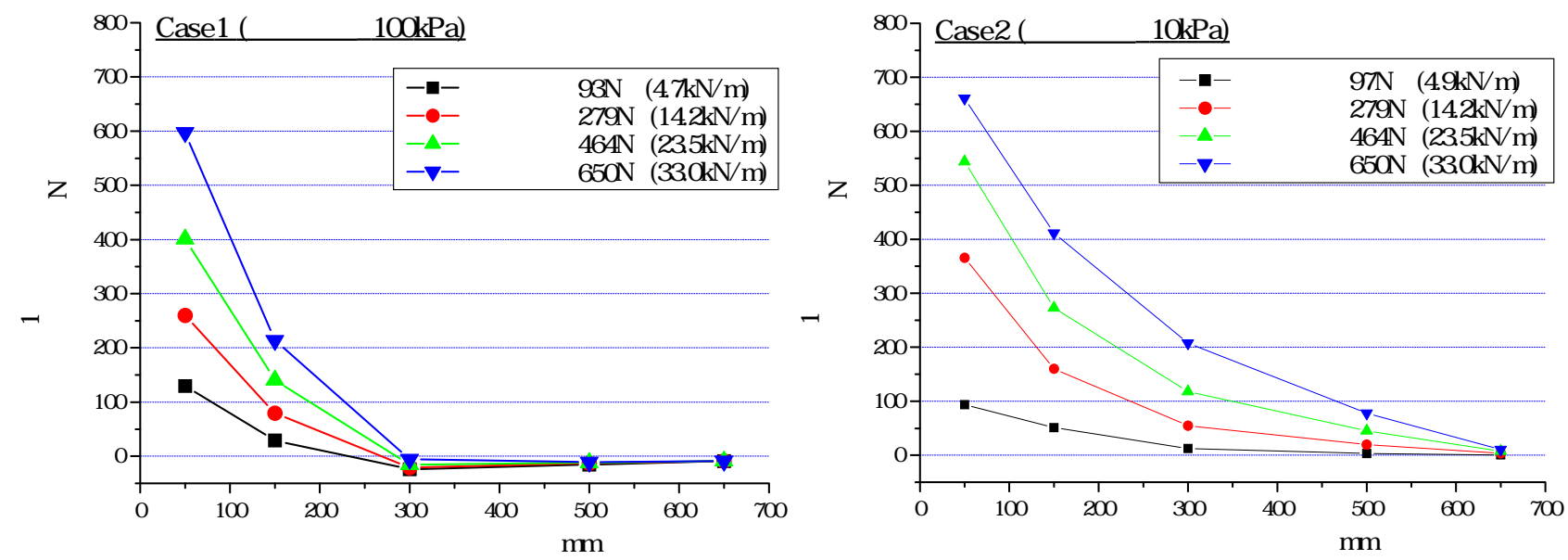

図-10 各載荷レベルにおける補強材張力の水平方向分布 (左図 : Case1, 右図 : Case2)

からの補強材の引抜け量か増加したが, 補強材は完全に 引抜けなかった . 最終的には補強材の引張強度の規格值 である $38 \mathrm{kN} / \mathrm{m}$ 付近で , クランプ (平チャック) 付近で 補強材力破断した。一方，Caselでは補強材か破断する まで土層背面からの補強材の引抜けは生じなかった．

図-9に引抜き力と載荷点における引抜き量の関係を示 す. 図中には, $35 \mathrm{kN} / \mathrm{m}$ 付近まで載荷した際の引抜き力 と引抜き量の勾配から補強材の引抜き岡性について示し ているが , 拘束圧が高いCase1では約 $7500 \mathrm{kN} / \mathrm{m} / \mathrm{m}$ 程度 ， 拘束圧の低いCase2では約 $4500 \mathrm{kN} / \mathrm{m} / \mathrm{m}$ 程度であり，拘束 圧か高い方か引抜き岡性か高いことが分かった . なお， 載荷最終段階において段階的に引抜き力が減少する傾向 が見られるが，これは載荷点近傍において補強材のスト ランドが1本ずつ破断したためである .

過去に実施された補強材引抜き試験によりセメント 改良磁土内に敷設された補強材の引抜き岡性に及ぼす拘 束圧依存性は小さいことか確認されているが，粒度調 整砕石の場合は拘束圧の影響が大きいことか確認された

図-10に各載荷レベルにおける補強材張力の水平方向 分布を示す.ここで補強材張力はひずみゲージの出力值 から算定している.Case1では引抜き力を増加させても 補強材張力の増加は載荷点から $300 \mathrm{~mm}$ 以内の領域に限ら
れているが, 拘束圧の低いCase2では引抜き力の増加に 伴って載荷点から $500 \mathrm{~mm}$ 以上離れた箇所にも補強材張力 か発生している.すなわち, 補強材に作用する張力の到 達深さは拘束圧の増加に伴い小さくなることが分かった .

図-9に示したように, 引抜き力と載荷点における引抜 変位量の関係から求めた引抜き岡性について, 載荷最 終段階においてCase1がCase2の1.6倍程度大きかった .こ

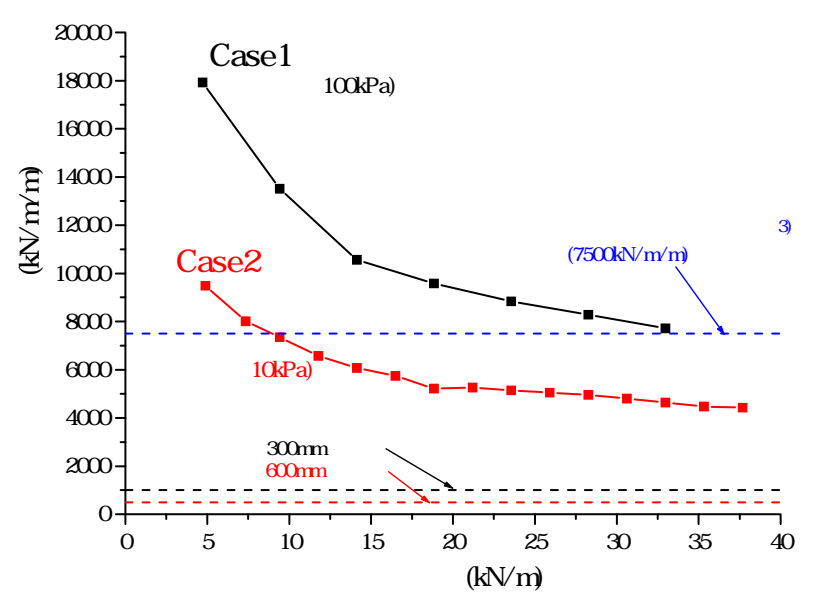

図-11 補強材の引抜き岡性と引抜き力の関係 (Case1, Case2) 
の引抜き岡性の違いについては, 図-10に示した補強材 の伸縮領域 (張力到達深さ) の比 (1.6倍程度) に概ね 合致する .すなわち, 粒調砕石中に敷設された補強材は 拘束圧の大きさに応じて伸縮領域力変化し, 弚れによっ て引抜き岡性力変化すると考えられる .

なお，過去に実施したセメント改良碟土中の補強材 の引抜き試験（図-3）における補強材の伸縮領域は 300mm程度であった（図-4）. 本研究で実施した実験で はセメント改良を行っていない粒調砕石を用いて地盤模 型を作成しているものの，拘束圧が高い場合 (Casel) の補強材の伸縮領域はセメント改良礫土中の補強材と同 レベルであることが分かる .

図-11に各載荷ステップで得られた引抜き岡性と各載 荷ステップにおける最大引抜き力の関係を示す . 引抜き 試験においては文献6と同樣に, 各載荷ステップにおい て3回の繰り返し載荷を実施しているため，ここに示す 引抜き剛性は各載荷ステップの最終載荷時 (3回目の繰 返し載荷時) の引抜き力と引抜き量の勾配 (図-9) から 算出している . 図中には比較のために, セメント改良磁 土中の補強材バネ值の設計用值 $(7500 \mathrm{kN} / \mathrm{m} / \mathrm{m}){ }^{3}$ も示し ている.この補強材バネ值の設計用値は, 気中で実施し た引張試験から算出した補強材のバネ定数 $\left(K_{\mathrm{gto}, 0}=200 \mathrm{kN} / \mathrm{m} / \mathrm{m}\right){ }^{4}$ を用い. 式(1)から算出したものであ り，図一に二示した実補強土橋台の水平載荷試験結果の逆 解析結果とも整合している。また，図中には二の補強材 の気中岡性 (補強材バネ值の設計用值) も示しているが， その際には図-10の)結果を考慮し, 補強材長さ (伸縮領 域) か300mm，600mmの場合の2通りを示した .

この図より，引抜き力の増加に伴い引抜き岡性が減 少することが分かる.これは補強材自身の岡性が引抜き 力増加に伴い減少していることに加えて, 補強材の伸縮 領域（図-10）の増加に起因していると考えられる.

Case1，Case2を比較すると，拘束圧によって引抜き岡性 は異なるものの, 粒調杂卆石中に敷設した補強材の引抜き 岡性は, 気中岡性の設計用值よりも8〜10倍程度大きい ことが分かった .これは，(1)粒調杂石一補強材間て発揮 される摩擦力による岡性の増加，(2)補強材周辺の粒調砕 石の拘束により補強材の伸縮領域力限定されることによ る(見かけの) 岡性増加, に起因していると考えられる.

また，Case1の引抜き岡性はセメント改良磁土の補強 材バネ值の設計用値と同等以上であり，Case2は光れを 下回る結果となった .

（2）補強材の引抜特性に及ぼす補強材料の影響について 本節では, 補強材料の影響に着目して実施したCase3， Case4についての実験結果を示す . 表-3に示したように， Case3，4で用いた補強材は目合いの大きさがほぼ同等で あるが，文献4に示される気中岡性は約3.4倍異なる．

図-12に引抜き力と土槽背面からの補強材の引抜き量 の関係を示す . 盛土材料の内部摩擦角および補強材表面 での拘束圧から算出した補強材の引抜き強度の計算値 $(28 \mathrm{kN} / \mathrm{m})$ 付近で土槽背面からの引抜け量か増加した .

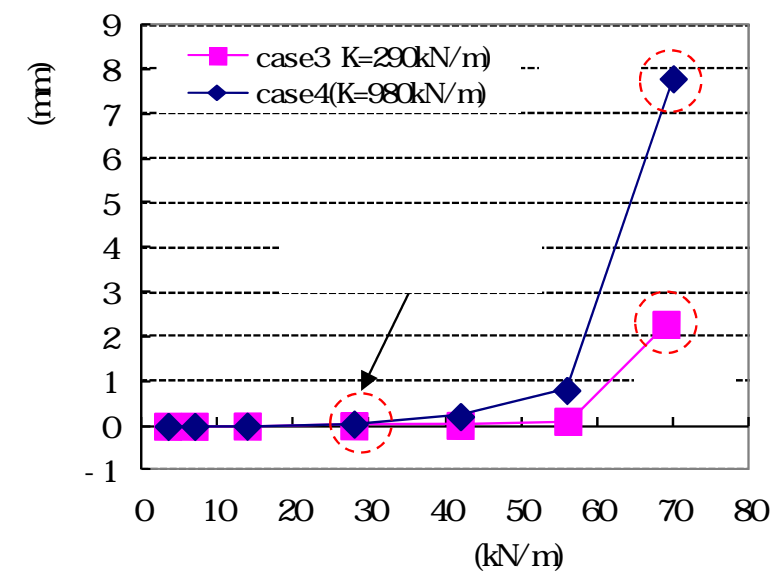

图 12 引抜き力と土槽背面からの引抜け量の関係 (Case3, Case4)
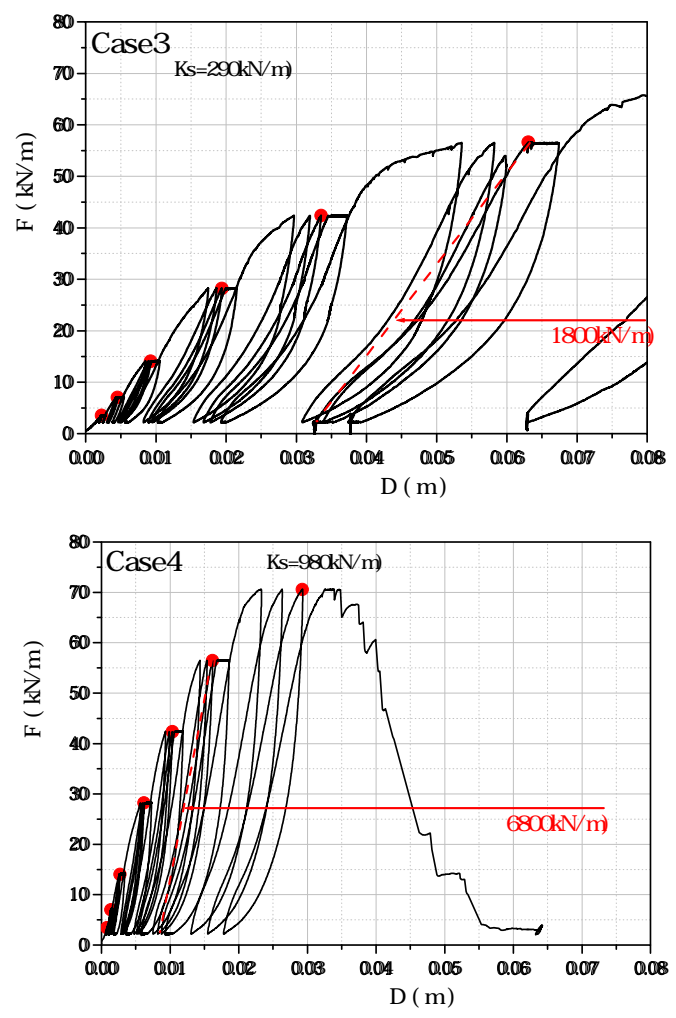

図-13 引抜き力と載荷点における引抜変位量の関係 (Case3, Case4)

しかしながらCase3, 4ともに引抜き強度の計算值で補強 材が引抜けるわけでなく，引抜き力が $70 \mathrm{kN} / \mathrm{m}$ 付近まで 増加した時に引抜けた . 引抜き強度の実験值は計算值よ りも約2.5倍大きいことから, 補強材の引抜き強度は補 強材表面の摩擦抵抗だけでな, 補強材の目合いにおけ る土粒子のかみ合わせ (インターロッキング) によって も発揮されていることが考えられる．また，Case3と Case4を比較すると, 気中岡性が高いCase4の方が引抜け 直前までの引抜け量が大きいことが分かる .

図-13に引抜き力と載荷点における引抜き量の関係を 示す. 図中には, $55 \mathrm{kN} / \mathrm{m}$ 付近まで載荷した際の引抜き 力と引抜き量の勾配から補強材の引抜き岡性について示 しているが, 気中岡性が高いCase4では約 $6800 \mathrm{kN} / \mathrm{m} / \mathrm{m}$ 程 

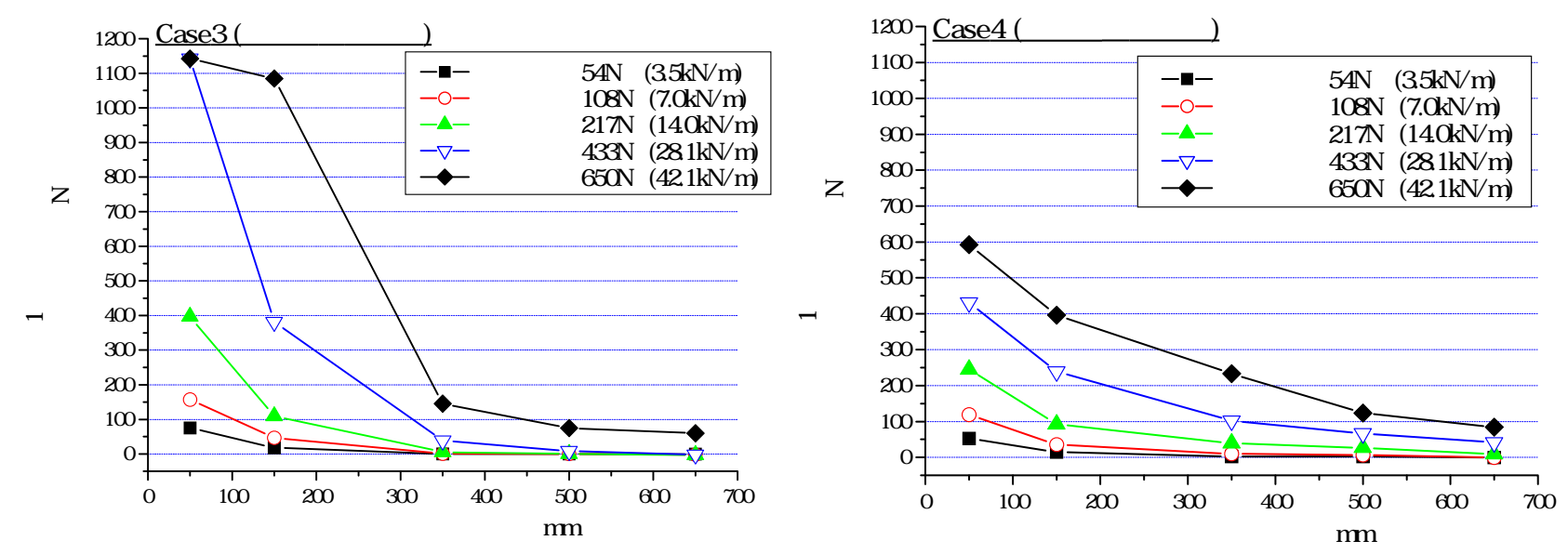

図-14 各載荷レベルにおける補強材張力の水平方向分布 (左図 : Case3, 右図 : Case4)

度, 気中岡性の低いCase3では約 $1800 \mathrm{kN} / \mathrm{m} / \mathrm{m}$ 程度であっ た。

図-12および図-13よりCase3の載荷最終段階における載 荷点近傍における引抜変位量は $120 \mathrm{~mm}$ 程度であるのに対 して土槽背面からの引抜け量は2mm程度であった .一方， 高岡性の補強材を用いたCase4では光れ午れ $25 \mathrm{~mm}$ と $8 \mathrm{~mm}$ であり，Case3の土中の補強材の伸長量はCase4の7倍程度 であった .これは, 補強材の気中岡性 (Ks，表-3参照) の比 (約3.4倍) よりもはるかに大きい.

図-14に各載荷レベルにおける補強材張力の水平方向 分布を示す. Case3はCase4と比較して, 引抜き力の増加 に応じて補強材張力か奥行き方向に伝達されにくく, 載 荷点近傍て抵抗力か発揮されていることが分かる.これ は，気中岡性が低いCase3では補強材自身が伸びやすく， 補強材の伸縮力載荷点近傍に集中するために補強材全体 に張力が伝達しにくかったと考えられる. 引抜き力が $433 \mathrm{~N}(28.1 \mathrm{kN} / \mathrm{m})$ の段階から $650 \mathrm{~N}(42.1 \mathrm{kN} / \mathrm{m})$ の段階に至る 際にCase3では載荷点近傍 (50mm離れ) の張力が上昇せ ず，炎の背面の張力計測位置 (載荷点から $150 \mathrm{~mm}$ 離れ) の張力が上昇している.これは載荷点近傍付近の粒調砕 石-補強材間て抵抗力地増加しにくくなり，張力の負担 が炎の背面に遷移したことを示している．一方でCase4 ではこのような傾向が見られず，引抜き力が上昇しても 発揮される張力は載荷点から遠ざかるについて漸减して いることが分かる.

これらの挙動の違いは, 補強材の岡性差に伴う土中 での補強材の伸ひひずみの違いに起因していると考えら れる.すなわち，岡性の高い補強材を用いた場合，粒調 砕石一補強材間に生じる相対変位が小さ, さらに補強 材張力か奥まて伝達されやすい，弚のため，広域に渡っ て有効な引抜抵抗力力発揮され，弚の結果，高い引抜き 岡性力発揮されると考えられる.一方, 岡性の低い補強 材を用いた場合, 粒調艻卆石一補強材間の相対変位が大き く, 補強材表面の摩察や補強材目合し部におけるインタ 一ロッキングによって発揮されている抵抗力が失われや すい.さらに, 補強材張力か奥まで伝達されにくいため， 狭い範囲で引抜抵抗力か発揮されやすい傾向がある.

図-15に補強材の引抜き岡性と引抜き力の関係を示す．

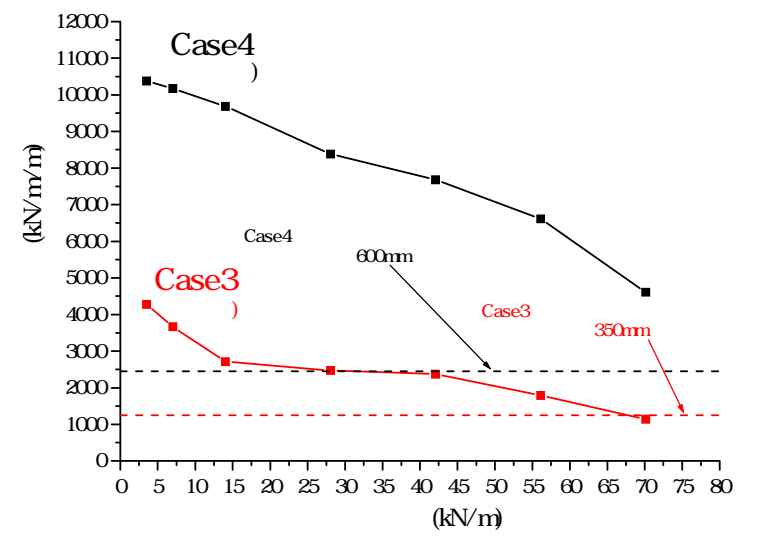

図-15補強材の引抜き岡性と引抜き力の関係 (Case3, Case4)

図中には比較のために, 実験に用いた補強材の気中岡性 (補強材バ神值の設計用值) もプロットしているが，光 の際には図-14の結果を考慮して補強材長さ (伸縮領 域) をCase3では350mm，Case4では600mmと設定した . Case3の引抜き岡性は気中岡性の1 3.5倍程度であるのに 対して，Case4は2-4倍程度である。光れ光れ同じ拘束圧 下で実施された実験にもかかわらず，Case4の方が気中 岡性に比して引抜き岡性がきいことが分かる .これは 前述したようにCase3では粒調砕石 - 補強材間の相対変 位が大きく，載荷に伴い補強材周辺の地盤力乱れたため に，地盤の拘束効果力低くなったと考えられる．これは 実験後の補強材周辺の観察でも確忍された .

\section{6.まとめ}

本研究ては, 粒調艻石中に埋設した補強材の引抜き岡 性に及ぼす拘束圧の影響および補強材料の影響を評価す るために引抜き試験を実施した . 乥の結果，以下の知見 が得られた。

（1）補強材の引抜特性に及ぼす拘束圧の影響

1. 補強材の引拔抵抗力は, 盛土材料の内部摩擦角およ び補強材表面での拘束圧から算出した補強材の引抜 
き強度より高かった .これは , 引抜抵抗力が表面の 摩擦だけでなく, 補強材の目合いにおける土粒子の かみ合わせ (インターロッキング) によっても発揮 されたためだと考えられる

2. 高拘束圧下における補強材の引抜き岡性はセメント 改良磁土内に敷設された補強材の引抜き岡性と同程 度となった .一方, 同一の補強材であっても低拘束 圧下においては補強材の引抜き岡性が咸少した。

3. 拘束圧力高い場合, 補強材周辺の粒調砕石の拘束に より補強材の伸縮領域 (張力到達深さ) 力限定され た . 引抜き力を増加させても補強材張力は奥に伝達 されにくい傾向か得られた .

4. 拘束圧による引抜き岡性の違いは, (1)粒調砕石一補 強材間て発揮される抵抗特性に及ぼす拘束圧の影響， (2)補強材の伸縮領域に及ぼす拘束圧の影響，に起因 していると考えられる

5. 拘束圧によって引抜き岡性は異なるものの, 粒調砕 石中に敷設した補強材の引抜き岡性は, 気中岡性の 設計用値よりも8〜10倍程度大きいことを確認した 。

\section{（2）補強材の引抜特性に及ぼす補強材料の影響}

1. 岡性の高い補強材を用いた場合, 粒調砕石 - 補強材 間に生じる相対変位が小さく，さらに補強材張力が 奥まて伝達されやすい，光のため, 広域に渡って有 効な引抜抵抗力か発揮され, 弚の結果, 高い引抜き 岡性力発揮されると考えられる。

2. 補強材の岡性力゙低い場合, 補強材の伸縮領域力載荷 点近傍に限られる傾向があり, 補強材の岡性が高い 場合と比較して補強材張力が奥に伝達されにくいこ とが分かった .

\section{7 . 今後の実務設計上の課題}

本検討では, 補強材の引抜き岡性に及ぼす拘束圧の影 響および補強材料の岡性の影響について検討した . 今後 はこの結果を元に, 粒調砕石て構築された背面盛土 (ア プローチブロック) 中に敷設された補強材の引抜き岡性
の設計用値を示していきたいと考えている . 谷の場合， 拘束圧の大きさや補強材自身力持入岡性により，粒調砕 石-補強材間で発揮される抵抗力, および張力到達深さ か変化することを考慮する必要がある。

また，3章て述べたようにGRS一体橋梁の設計法の確 立のためには橋桁の温度収縮に伴う繰り返し載荷を受け た場合の補強材の引抜き特性の評価か不可欠である．今 後，さらに試験を実施し，評価法を確立したいと考えて いる。

謝辞 : 引抜き試験の実施に際しては, 載荷手法について 防衛大学校平川講師の御指導をいただいた .ここに深謝 の意を表する

\section{参考文献}

1)龍岡文夫, 舘山勝, 平川大貴, 渡辺健治, 清田隆 : GRS一体 橋梁の特徵と開発経緯 , ジオシンセティックス論文集 , 第24 巻, 2009.12

2)Tatsuoka, F., Hirakawa, D., Nojiri, M., Aizawa, H., Nishikiori, H., Soma, R., Tateyama, M. and Watanabe, K.: A new type integral bridge comprising geosynthetic-reinforced soil walls, Geosynthetics International, IS Kyushu 2007 Special Issue, Vol.16, No.4, pp.301-326, 2009

3)国土交通省鉄道局監修 鉄道総合技術研究所編: 鉄道構造物 等設計標隼・同解説 土留め構造物 , 2012.1

4) R R R工法拹会 : R R R - B工法 材料マニュアル , 2008.8 5)青木一二三 , 米澤豊司 , 渡邊修, 舘山勝, 龍岡文夫 : ジオテ キスタイルを用いたセメント改良補強土橋台の現地載荷試験 結果，ジオシンセティックス論文集，第18巻，2003

6)内村太郎, 龍岡文夫, 青木一二三, 米澤豊司, 北野陽堂, 舘 山勝, 渡辺健诒, 田村幸彦, 枡尾孝之 : セメント改良粒調砕 石盛土中のジオグリッド補強材の引拔試験，ジオシンセティ ックス論文集 , 第18巻 , 2003

7)須賀基晃, 野中隆博, 栗山亮介, 神田政幸, 舘山 勝 : 補強 盛土一体橋梁 (GRS一体橋梁) の鉛直及び水平載荷圾験，第 47回地盤工学研究発表会, 2012

\title{
PULLOUT STIFFNESS CHARACTERISTICS OF GEOGRID ENBEDDED IN WELL-GRADED GRAVEL
}

\author{
Kenji WATANABE and Ryosuke KURIYAMA
}

\begin{abstract}
In this study, pullout tests of geogrid embedded in well-graded gravel were performed, in order to establish the design procedure of GRS integral bridge which was proposed as a new type of bridge abutment using reinforced-soil method. The pullout tests were focused on the effect of confining pressure and stiffness of geogrid on the pullout stiffness characteristic of geogrid. The experiments revealed that the pullout stiffness was largely affected by the confining pressure. This is due to the increase of friction and inter-rocking resistance mobilized between the geogrid and the gravel as well as the decrease of free length of geogrid. The pullout stiffness of geogrid was also affected by the relative displacement between the geogrid and the gravel.
\end{abstract}

KEYWORDS: Geogrid, pullout test, pullout stiffness, GRS integral bridge, performance-based design 